\title{
SPECIFIKA MALÉHO PODNIKÁNÍ V ČESKÉ REPUBLICE
}

\section{THE SPECIFICS OF SMALl BUSINESS IN THE CZECH REPUBLIC}

\author{
Jana Frkova \\ University of Chemistry and Technology, Faculty of Chemical Engineering, Technicka 5, 16628 Prague, \\ Czech Republic
}

\begin{abstract}
Abstrakt - CZ
Malé podnikání v Česku vykazuje odlišnosti oproti „standardu“ v zemích EU. Je zde velká „hustota“ podnikatelských subjektů v přepočtu na obyvatele, mikropodnikatelé se vyznačují velkou neochotou zaměstnávat zaměstnance a nezvykle velké procento podnikatelů podniká současně vedle svého zaměstnávání. Navíc, $v$ době přiznivého růstu české ekonomiky, malé podnikání nejeví známky růstu. Pozitivní zpráva je, že v oblasti IT soukromí investoři jeví velký zájem o investice do mladých start up firem.
\end{abstract}

\section{Klíčová slova - CZ}

Malé a střední podniky; Česká republika; Evropská unie.

\begin{abstract}
EN
Small Businesses in the Czech Republic have basic differences between the "standard" in the EU countries. There is a large "density" of enterprises per capita, micro enterprises are characterized by a great unwillingness to employ staff and an unusually large percentage of micro-enterprises are simultaneously engaged in employment here. Moreover, at the time of the favorable growth of the Czech economy, small businesses ate stagnating. The positive news is that in the area of IT, private investors are very interested in investing in young startups.
\end{abstract}

\section{Keywords - EN}

Small and Medium Enterprises; the Czech Republic; European Union

\section{JEL Classification}

M Business Administration and Business Economics $\bullet$ Marketing $\bullet$ Accounting $\bullet$ Personnel Economics M1 Business Administration

M13 New Firms • Startups

DOI: $\underline{\text { https://doi.org/10.14311/bit.2016.02.02 }}$

Editorial information: journal Business \& IT, ISSN 2570-7434, CreativeCommons license (c) (1) published by CTU in Prague, 2016, http://bit.fsv.cvut.cz/ 
Malé a střední podniky, dále jen MSP, tvoří páteř každé ekonomiky [1 ]. Prokažme tento fakt na výmluvných statistikách nejdř́ve pro ČR a následně za EU jako celek. Podle Zprávy o vývoji malého a stredního podnikání a jeho podpoře $v$ roce 2015 [2 ], kterou uveřejňuje Ministerstvo průmyslu a obchodu každoročně, dále jen Zpráva MPO 2015, je celkový počet MSP stabilní již po několik let, jak je patrné z obrázku č. 1.

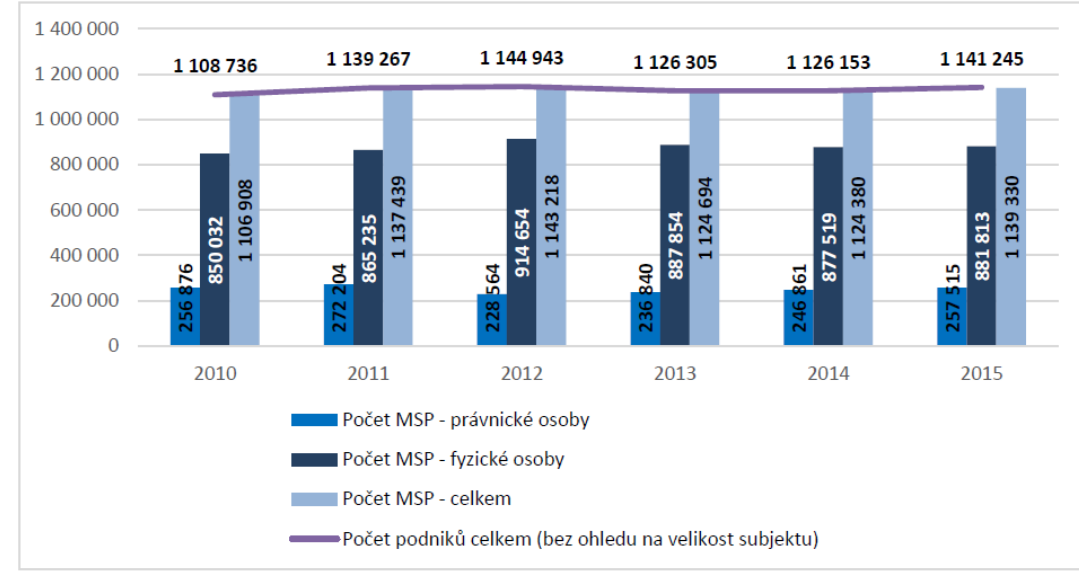

Obrázek 1: Počet MSP v členění na právnické osoby a fyzické osoby

Zdroj: [2]

Podle Annual Report on European SMEs 2015/2016 [3], dále jen Annual Report, Česká republika vede evropskou statistiku v hustotě „populace“ MSP v přepočtu na sto obyvatel, která se pohybuje od 2,2 $\vee$ Rumunsku do $9.4 \vee$ ČR, jak je patrné z obrázku 2.

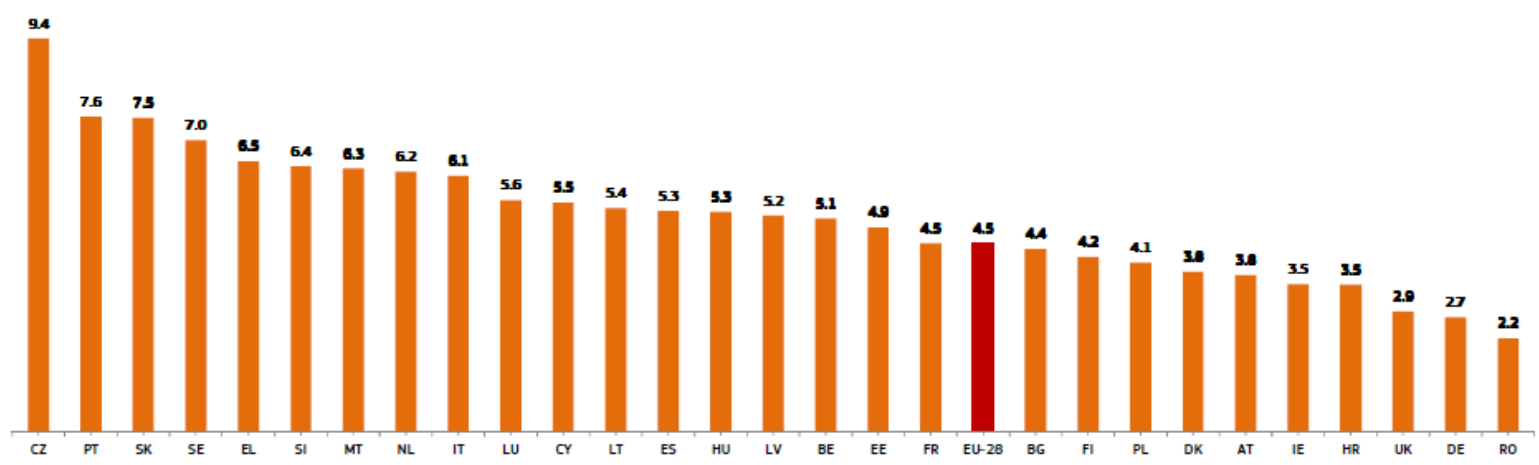

Obrázek 2: Počet MSP připadající na sto obyvatel

Zdroj: [3]

Toto číslo by se mohlo zdát pro ČR povzbudivé, ale při podrobnějším zkoumání zjistíme [3], že $92 \%$ podnikatelských subjektů není ochotno mít zaměstnance a má počet zaměstnanců 0,7 \% subjektů má počet zaměstnanců do výše 4 . Co je dále zneklidňující je to, že klesá počet podnikatelů vykonávajících podnikání jako hlavní činnost - viz obrázek 3. To znamená, že byt' celkový počet podnikatelů fyzických osob neubývá, ubývá těch, kteří mají podnikání jako jediný zdroj př́ijmů. Tedy stále větší počet podnikatelů řeší svoje podnikání v kombinaci se zaměstnáním (cca 41 \% v r. 2015 [4], přitom v r. 2012 
to bylo $37 \%)$. Nabízí se jediná odpověd', samotné podnikání je neuživí. Tak vysoké procento podnikatelů podnikajících $v$ souběhu se zaměstnáním, to je skutečný fenomén Česka. Je to dáno tolerancí zaměstnavatelů, kterým nevadí souběžné podnikání svých zaměstnanců. Česká legislativa to umožňuje sice $s$ podmínkou, že zaměstnavatel musí udělit souhlas $s$ vedlejší výdělečnou činností svého zaměstnance, pokud má zaměstnanec vedlejší př́imy ve stejném oboru, $v$ jakém působí zaměstnavatel. Lze sice $v$ pracovní smlouvě zavázat zaměstnance $k$ zákazu výkonu veškeré jiné výdělečné činnosti, avšak evidentně se tento institut př́liš v praxi nevyužívá.

\begin{tabular}{|l|r|r|r|}
\hline & Hlavni činnost & Vedlejší činnost & \multicolumn{1}{c|}{ Celkem } \\
\hline K 31. 12.2015 & 578544 & 397408 & 975952 \\
\hline K 31. 12.2014 & 586112 & 386244 & 972356 \\
\hline K 31. 12.2013 & 602395 & 374833 & 977228 \\
\hline K 31. 12.2012 & 627596 & 366492 & 994088 \\
\hline K 31. 12.2011 & 649990 & 351774 & 1001764 \\
\hline K 31. 12.2010 & 640406 & 336663 & 977069 \\
\hline
\end{tabular}

Obrázek 3: Počet podnikatelů v letech 2010 - 2015 na hlavní a vedlejší činnost

Zdroj [2]

Nechme počty stranou a podívejme se, jak se MSP podílí na zaměstnanosti. Podle Zprávy MPO 2015 [2] činil podíl zaměstnanců MSP na celkovém počtu zaměstnanců podnikatelské sféry 58,9 \%, což jistě není zanedbatelné číslo. Bohužel se však zaměstnanost $v$ tomto sektoru snižila o 7000 zaměstnanců, tj. o 0,38 \% oproti roku 2014. Na výkonech se MSP podílely $49 \%$, což představuje oproti roku 2014 pokles o dva procentní body. Na celkové přidané hodnotě podnikatelské sféry se v r. 2015 MSP podílely $54,1 \%$, což je téměř shodné číslo s rokem 2014. Přitom průměrná měsíční mzda v MSP činila v r. 201522.708 Kč a byla nižší o 11,56 \% v porovnání s průměrnou mzdou v celé podnikatelské sféře, tj. včetně velkých podnikatelských subjektů ( 25.676 Kč). Ovšem dobrou zprávou a příslibem dobré budoucnosti je údaj o investicích. „Investice malých a středních podniků v roce 2015 dosáhly 391571 mil. Kč, což činí na celkových investicích podnikatelské sféry v roce 2015 59,85\%, což představuje zvýšení o 2,54 \% procentního bodu oproti roku 2014.“ [2]

Na základě těchto klíčových ukazatelů však musíme konstatovat, že přestože ekonomika Česka vykazovala v létech 2014 a 2015 slušný hospodářský růst - meziroční růst HDP v r. 2015 činil 4,3\% [4] o rozvoji MSP podle výše uvedených čísel to rozhodně tvrdit nemůžeme.

Annual Report o stavu MSP v Evropě EU-28 [3] přináší mnohem optimističtější závěry: MSP představovaly $v$ roce 2015 dvě třetiny pracovních míst a $z$ tři pětin tvorbu přidané hodnoty $v$ nefinančním sektoru. Převážná většina malých a středních podniků jsou mikropodniky s méně než 10 zaměstnanci a představují téměř $93 \%$ všech podniků. Zpráva tvrdí, že v r. 2015 se malým a středním podnikům konečně podařilo překonat dopady hospodářské a finanční krize z let 2008 a 2009. Po řadu let nepříznivé ekonomické výkonnosti v evropských státech byl v roce 2015 dobrý růst přidané hodnoty již druhým rokem v radě (3,8 \% v roce 2014 a 5,7 \% v roce 2015). Také poprvé v těchto letech u MSP stoupla zaměstnanost v roce 2014 (1,1\%), v roce 2015 se zaměstnanost zvýšila o 1,5 \%. Malé střední podniky vykázaly dobrý rok 2015 téměř ve všech členských státech. Vylepšený výkon malých středních podniků je odrazem lepších makro ekonomických podmínek a to zejména zvýšení domácí poptávky v EU. Ta je obzvláště důležitá pro malé a střední podniky, nebot' působí v odvětvích, které mají nízkou intenzitu exportu. 
Podle Annual Report [3] v sektoru "high-tech" některé členské státy zaznamenaly obzvlášt́ vysoký růst zaměstnanosti v MSP, Litva (9\%), Velká Británie (11\%), Slovensko (12\%). Naopak, v řadě členských států byly zaznamenán $v$ této oblasti velký pokles zaměstnanosti Rumunsko (-9\%), Finsko (6\%) - viz obrázek 4.

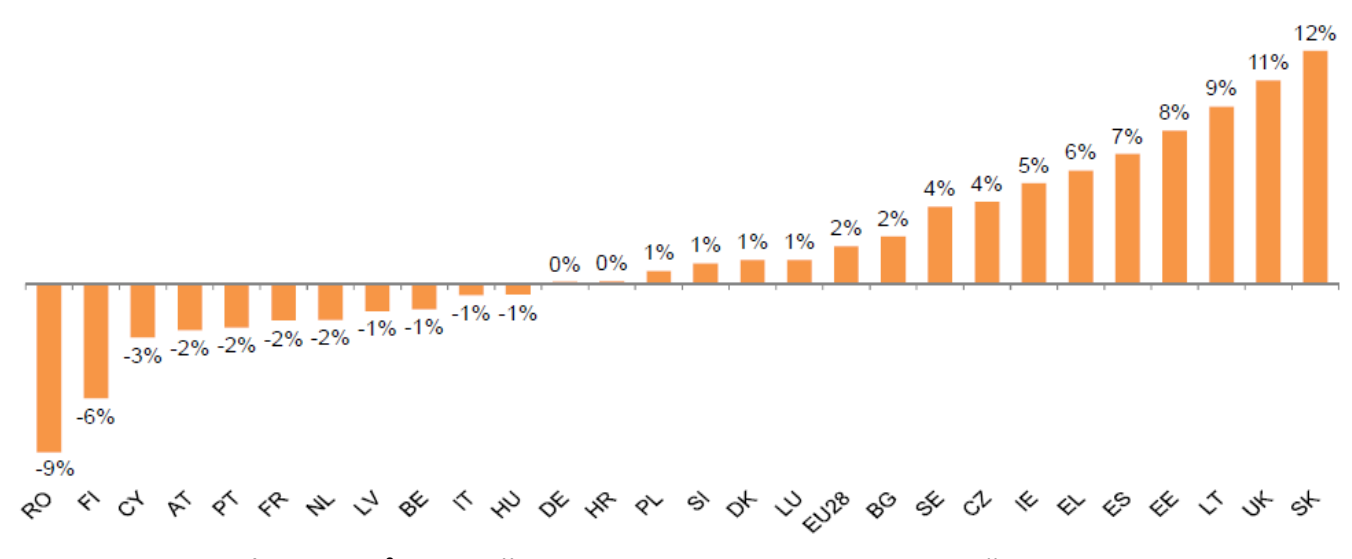

Obrázek 4: Růst zaměstnanosti v sektoru „high-tech“ v MSP v EU.

Zdroj: [3]

Start up firmy jsou kličcovými přispěvateli dynamiky inovací a růstu hospodářství nejen v EU, ale i na celém světe [5], [6], [7]. Avšak mnoho mladých podniků selhává ve svých prvních letech. [3] Vysoká úmrtnost je nepochybný fenomén, viz obrázek 5 , kde vidíme \% přeživších MSP po prvním a druhém roce své existence. Největší šanci na přežití kritických raných let mají švédské firmy, kde se druhého roku dožije 84 \% firem. Nejnižší procento přežití vykazují firmy v Portugalsku a Litvě, druhého roku se dožije pouze 50 \% MSP. V Česku se druhého roku dožije 64 \% firem.

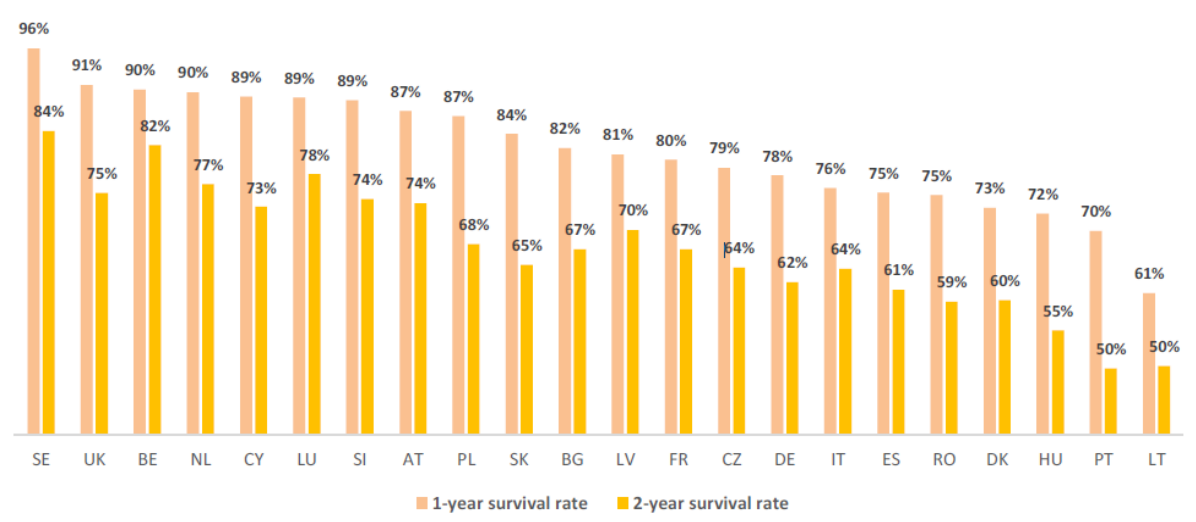

Obrázek 5: \% přeživších MSP po prvním a druhém roce své existence

Zdroj: [3] 
Příznivé je, že pokud se podíváme na počet zaměstnanců v MSP z hlediska úmrtnosti v průměru za EU-28, 63\% firem s 0 zaměstnanci nepřežije druhý rok, firmy s více než 10 zaměstnanci dosahují mnohem vyšší procento přežití druhého roku a to 82 \% [3]. Viz obrázek 6.

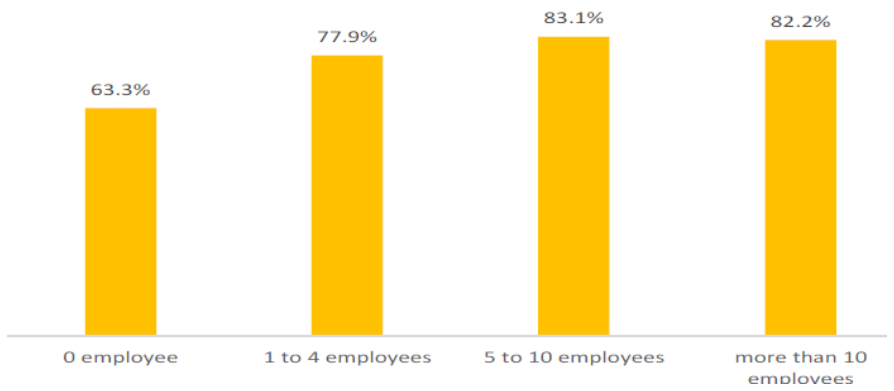

Obrázek: \% přeživších MSP po druhém roce v rozlišení podle počtu zaměstnanců

Zdroj: [3]

Jako největší překážkou v podnikání se jeví finanční náročnost při rozjezdu a zisk, který nabíhá se zpožděním, což způsobuje neschopnost podniku dostát svým závazkům, tzv. platební neschopnost podniku [8]. Státy by měly vytvářet politiku podpory právě pro takovéto začínající podniky a vytvořit přiznivé prostředí také z hlediska možnosti poskytnutí druhé šance, pokud mladá firma napoprvé neuspěje. Podnikatelé a manažeři by neměli být stigmatizováni, když selže jejich poctivé podnikatelské úsilí. Konkurzní řizení (konkurz je způsob řešení úpadku (bankrotu) podniku, který je způsoben nadměrnými a dlouhodobě nesplácenými závazky) $v$ jednotlivých státech EU se značně liší v tom, jaké „potrestání“ čeká čestné podnikatele, jejichž byznys selhal. Zdlouhavé insolvenční rízení odrazuje potenciální podnikatele od znovuzahájení podnikání. Podnikatelé se bojí potenciálního rizika úpadku a jeho důsledků a zabraňuje poctivým podnikatelům, jejichž podnikání jednou selhalo, začít znovu. $V$ důsledku toho se státy s více represivními konkurzními režimy zbavují přidané hodnoty a zaměstnanosti, které by mohly vytvořit start-up podniky a spiše odstrašují nebo znemožňují podnikatelům restart podnikání. Klíčová otázka: Trestat neúspěch v podnikání nebo naopak nabídnout druhou šanci? EU již koncem r. 2016 předložila návrh SMĚRNICE EP A RADY o rámcích pro preventivní restrukturalizaci, druhé šanci a opatřeních ke zvýšení účinnosti postupů restrukturalizace, insolvence a oddlužení. [9] Směrnice stanovuje „společná insolvenční pravidla pokrývající širokou škálu opatření od včasného zásahu, než se podnik dostane do vážných potiží, a včasné restrukturalizace, aby se zajistilo zachování životaschopných částí podniku, přes zpeněžení aktiv, pokud nelze společnost jinak zachránit, až po poskytnutí druhé šance poctivým podnikatelům prostřednictvím oddlužení.. Podle směrnice by platilo to, že podnik v nesnázích by měl co nejdříve přístup k preventivní restrukturalizaci dluhů. $V$ několika členských státech však dlužníci nemohou restrukturalizovat dluhy u svých věřitelů, dokud se skutečně nedostanou do platební neschopnosti, což už je samožrejmě pozdě. Podnikatelé jsou chyceni $v$ dluhových pastích někdy déle než 3 roky, než se mohou zbavit svých dluhů a začít znovu. Přiliš dlouhé trvání restrukturalizace, insolvence a oddlužení následně způsobuje nízkou míru výtěžnosti úvěrů. Směrnice cílí na to snížit zbytečné likvidace životaschopných podniků, zabránit zbytečným ztrátám pracovních míst, zabránit hromadění úvěrů, snížit náklady a zvýšit príležitosti pro poctivé podnikatele, kterým by měla být dána druhá šance začít znovu.

Počet malých a středních podniků, zejména mikro podniků, se tedy neustále mění a každý rok vzniká mnoho nových podniků a mnoho z nich přestane fungovat. Zejména hlavně mladé a malé firmy vykazují vysokou míru úmrtnosti. Start-up společnosti zejména v oblasti IT technologií jsou klíčovými 
přispěvateli inovací a dynamického růstu hospodářství [10], nicméně mnoho mladých podniků selhává ve svých raných letech. Pokud by existoval v České republice veřejný zájem a politika, která by silně podporovala start-up podniky nejen formou výhodných finančních injekcí (o fondu rizikového kapitálů se hovoří již několik let a dosud nebyl spuštěn) a např́iklad i tím, že umožní v nákladech jednorázově zohlednit výdaje na prípravu a náběh výroby a dále namísto zdlouhavých insolvenčních řizení poskytovala druhou šanci začít, přispělo by to $k$ žádoucímu rozvoji MSP.

Bílé místo $v$ oblasti fondů rizikového kapitálu podporovaných veřejnými prostředky $v$ Česku a soustřed'ující se na oblast High tech a IT zaplňuje soukromý kapitál. Velmi významným investorem v poslední době je StartupYard, startupový technologický akcelerátor se sídlem v Praze. StartupYard se zaměřuje na investice do technologických firem pocházejících především ze střední Evropy. V poslední době získává nemalé finanční prostředky prostřednictvím crowdfundingové investiční platformy. $V$ průběhu roku probíhá několik akceleračních kol. Vybrané prostředky od soukromých investorů jsou následně investovány jako prrimá investice do vybraných technologických start up firem. Pokud se firma ukáže jako úspěšná, může být $v$ dalších kolech znovu podpořena. Mezi přihlášenými vedou startupy z České republiky a Mad'arska a počet a kvalita startupů roste. StartupYard si vybírá projekty a lidi s nadějnými nápady a kromě finanční investice jim předává svoje zkušenosti.

\section{Závěr}

Malé podniky jsou důležitým článkem ekonomiky, jejím významným stabilizujícím prvkem nejen z hlediska ekonomického a sociálního, ale i z hlediska politického, nebot' jejich majitelé tvoří střední tř́du, která politicky stabilizuje společnost. I přes tento nepopiratelný prínos neexistují v ČR žádné významné všeobecně uplatnitelné nástroje, které by podstatným způsobem pomohly stabilizaci malého podnikání a především start up firem.

\section{References}

[1 ] SOROOSHIAN, S., MOHD MUSTAFA, A. A business destiny forecast model. Quality - Access to Success. pp. 150-155. ISSN: 15822559.

[2] MINISTERSTVO PRŮMYSLU A OBCHODU: Zprávy o vývoji malého a středního podnikání a jeho podpoře $v$ roce 2015. MPO. Dostupné na https://www.mpo.cz/assets/cz/podnikani/male-a-strednipodnikani/studie-a-strategicke-dokumenty/2016/11/Zprava MSP 2015.pdf [15 [12 Oct 2016].

[3] EUROPEAN COMMISION: Annual Report on European SMEs 2015/2016. Dostupné na https://ec.europa.eu/irc/sites/ircsh/files/annual report - eu smes 2015-16.pdf [15 Nov 2016 ].

[4] ČESKÝ STATISTICKÝ ÚŘAD. Statistická ročenka 2016. Dostupné na http://apl.czso.cz/pll/rocenka/rocenka.indexnu [15 Sept 2016].

[5] KAMIŃSKA, A., PARKITNA, A., GÓRSKI, A. Factors determining the development of small enterprises. Advances in Intelligent Systems and Computing. International Conference on Information Systems Architecture and Technology, ISAT, pp. 197-209. ISSN: 21945357. https://doi.org/10.1108/14637150110392773

[6] O'DWYER, M., GILMORE, A. Competitor orientation in successful SMEs: an exploration of the impact on innovation. Journal of Strategic Marketing. pp. 1-17.

[7] APANASOVICH, N., ALCALDE-HERAS, H., PARRILLI, M.D. A new approach to business innovation modes: the 'Research, Technology and Human Resource Management (RTH) model' in the ICT sector in Belarus. European Planning Studies, pp. 1976-2000. ISSN: 09654313. • https://doi.org/10.1080/09654313.2017.1322040 
[8] BELÁS, J., MIŠANKOVÁ, M., SCHÖNFELD, J., GAVUROVÁ, B. Credit risk management: Financial safety and sustainability aspects. Journal of Security nad Sustainability Issues, pp. 79-94. ISSN: 20297017

[9] EUR - Lex. Návrh SMĚRNICE EP A RADY o rámcích pro preventivní restrukturalizaci, druhé šanci a opatřeních ke zvýšení účinnosti postupů restrukturalizace, insolvence a oddlužení. Dostupné na https://ec.europa.eu/transparency/regdoc/rep/1/2016/CS/COM-2016-723-F1-CS-MAIN-PART-1.PDF [15 June 2016 ].

[10] DLASK, P. Simulation model based on regional development and virtual changes. Acta Polytechnica. 5-2015, pp. 291-300. ISSN 1210-2709. 